\title{
Quality of millet seeds at different positions of the panicle ${ }^{1}$
}

\author{
Juliana Martinatti ${ }^{2}$, Erikson Kadoshe Morais Raimundo ${ }^{2}$, \\ Marina Barros Zacharias², Patricia Marluci da Conceição ${ }^{3}$, Victor Augusto Forti ${ }^{2}$
}

\section{ABSTRACT}

Many factors may interfere in the quality of millet seeds; however, it is not known whether the location at different positions of the panicle may affect this quality. This study aimed to evaluate the quality of millet seeds produced at different positions of the panicle using uniformity, 1,000seed mass, water content, X-ray, germination, seedling length, seedling dry matter mass, cold and health tests. The panicles were divided into five equidistant portions (proximal 1, proximal 2, intermediary, distal 1 and distal 2), starting from the panicle insertion. It was observed that there are differences among the positions of the seeds in the panicles related to the physical, physiological and health characteristics. The seeds located at the ends of the panicles presented a lower mass and physiological potential. The highest occurrence of Fusarium sp. was verified in the seeds from the proximal 1 portion, what might indicate a possible cause for the reduction in the physiological potential. Seeds from the intermediary portion present a higher mass, percentage of intact seeds and physiological potential.

KEY-WORDS: Penissetum glaucum (L.) R. Br., X-ray test, seed health.

\section{INTRODUCTION}

Millet [Penissetum glaucum (L.) R. Br.] has gained importance in Brazil because of its characteristics of rusticity, such as drought resistance, withstanding prolonged water deficit and rainfall below $400 \mathrm{~mm}$ per year, adaptation to areas with low-fertility soil and resistance to high temperatures (Pereira Filho 2016). The trend to expand this crop occurs, mainly, in areas that aim at a good soil cover,

\section{RESUMO}

Qualidade de sementes de milheto em diferentes posições da panícula

Muitos são os fatores que podem interferir na qualidade de sementes de milheto; porém, não se sabe se a localização nas diferentes posições da panícula pode interferir nessa qualidade. Objetivou-se avaliar a qualidade de sementes de milheto produzidas em diferentes posições da panícula, por meio dos testes de uniformidade, massa de 1.000 sementes, teor de água, raios $\mathrm{X}$, germinação, comprimento de plântulas, massa de matéria seca das plântulas, de frio e de sanidade. As panículas foram divididas em cinco porções equidistantes (proximal 1, proximal 2, intermediária, distal 1 e distal 2), iniciando-se a partir da inserção da panícula. Observou-se que existem diferenças entre as posições das sementes nas panículas relacionadas às características físicas, fisiológicas e sanitárias. As sementes localizadas nas extremidades das panículas apresentaram menor massa e potencial fisiológico. A maior ocorrência de Fusarium sp. foi verificada nas sementes da porção proximal 1, o que pode indicar uma possível causa na redução do potencial fisiológico. Sementes na posição intermediária apresentam maior massa, porcentagem de sementes íntegras e potencial fisiológico.

PALAVRAS-CHAVE: Penissetum glaucum (L.) R. Br., teste de raios $\mathrm{X}$, sanidade de sementes.

for application under no-tillage (Pires et al. 2017) and production of grains, silage and grass, as a source of food for ruminants (Buso et al. 2014).

For the correct use and expansion of this crop, it is important to know all steps, including features related to seed quality and production. The seed quality concept refers to the determination of physical, physiological, genetic and health attributes, in order to find the best materials for plant propagation (Kong et al. 2020). The use of quality

${ }^{1}$ Received: Aug. 15, 2020. Accepted: Oct. 06, 2020. Published: Oct. 23, 2020. DOI: 10.1590/1983-40632020v5065026.

2. Universidade Federal de São Carlos, Centro de Ciências Agrárias, Departamento de Tecnologia Agroindustrial e

Socioeconomia Rural, Araras, SP, Brasil.E-mail/ORCID: juliana.martinatti@hotmail.com/0000-0002-3322-5033, kadoshetecagro@hotmail.com/0000-0001-7109-3273, marinazacharias@terra.com.br/0000-0002-5201-2981, viaugu@yahoo.com.br/0000-0003-2599-3603.

3. Universidade Federal de São Carlos, Centro de Ciências Agrárias, Departamento de Desenvolvimento Rural, Araras, SP, Brasil.E-mail/ORCID: patymarluci@gmail.com/0000-0002-9966-3191. 
seeds to guarantee uniformity of stand and yield is of great importance for the productive potential of plant species (Rossi et al. 2017).

One of the problems that millet has faced in the Brazilian trade is the low physical, physiological and health quality of the seeds, which are limiting factors for the expansion of this crop (Peske \& Novembre 2010). The physical quality refers to the integrity of seeds and seed lots, considering the physical purity and damages (Grzybowski et al. 2019); the physiological quality includes attributes related to germination and vigor, and demonstrates which seeds present viability and potential to generate seedlings in a faster and more uniform way, even in adverse field conditions (Han et al. 2014); and the health quality offers information on the presence or absence of pathogens related to the seeds (Santos et al. 2014).

Several studies have been performed to evaluate the effects that millet seeds may face during or after their formation, interfering in germination and vigor (Lawan et al. 1985, Sugri et al. 2011, Javorski et al. 2018). The size and mass of millet seeds may interfere in the emergence, plant density and grain yield (Gardner \& Vanderlip 1989). Nevertheless, for the process of seed production, it is unknown whether there is any interference of size and mass in the quality of millet seeds, considering their position in the panicle. This information is relevant, since it may help producers and companies to select the best portions of the panicle, optimizing the process of seed production with a better quality.

Mondo \& Cicero (2005) evaluated the causeand-effect relationship of corn seeds in different positions in the cob and its relation to seed quality and observed that the corn seeds presented different forms and sizes, depending on their position in the cob, and that morphological alterations evaluated by X-ray images in the embryonic axes may be responsible for the reduction of seed quality.

Conversely, Cossetin Neto \& Bonetti (2013) did not find any difference in the germination and vigor of maize landrace seeds derived from three portions of the cob. Nonetheless, evaluating the 1,000 -seed mass, it was possible to note differences among the positions, in which the seed from the basal position presented the highest values for mass, followed by the intermediary position and, lastly, the apical position. Other studies have been performed aiming at correlating the position of the seeds and their quality in oat (Alves \& Kist 2011), passion fruit (Silva et al. 2015) and castor bean (Fogaça et al. 2017) crops.

It is important to highlight that some millet seed production companies have been using pelletization or incrustation techniques in order to standardize the seed size and facilitate the sowing procedure. Thus, the homogenization of seed size may be an alternative for the use of such techniques that increase the final production cost.

The understanding of the interference of the seed position in the panicle, in relation to seed quality, may guarantee, for farmers, the sale of better seed lots. Therefore, this study aimed to evaluate the quality of millet seeds produced at different positions of the panicle.

\section{MATERIAL AND METHODS}

The production of the millet plants (Embrapa BRS 1501 cultivar) was performed in the field, at the Universidade Federal de São Carlos, in Araras, São Paulo state, Brazil (25 48'95'S and 75'31'215'W), in 2019.

After the production of the panicles, 20 panicles with similar sizes (approximately $30 \mathrm{~cm}$ in length) were harvested. These panicles were separated into five different portions (proximal 1, proximal 2, intermediary, distal 1 and distal 2), starting from the insertion of the panicle. The determination of these portions was performed considering the total length of the panicle, divided into five equidistant portions (approximately $6 \mathrm{~cm}$ for each portion). Each portion was manually threshed. The individualized portions of the 20 panicles were grouped for further physical, physiological and health characterization. The experiment was conducted in a completely randomized design, with 5 treatments (portions).

For physical characterization, the seed mass from each portion per panicle was determined using a precision scale. The uniformity test was performed using screen sieves with oblong holes, promoting the seed dimension separation by thickness. The seeds from each portion were sieved for one minute, in sieves arranged in a descending order, following the sequence: $2 \times 10,2 \times 12,3 \times 14,3 \times 16$ and bottom. After sieving, the mass of the seeds retained in each sieve or at the bottom was determined.

The water content was performed by drying the seeds in an oven at $105{ }^{\circ} \mathrm{C}$, for 24 hours (Brasil 2009a); while the 1,000-seed mass was evaluated 
considering eight replications with 100 seeds from each portion. After determining the mass of each replication, the mean was performed and the value extrapolated to 1,000 seeds.

The X-ray test was carried out to evaluate the seeds internal morphology, considering four replications of 25 seeds for each portion. The seeds were placed on a transparent acetate sheet to fix them in the same position, with the embryonic axis in a parallel position to the acetate sheet. The seeds were X-rayed with an automated MultiFocus Digital Radiography System (Faxitron Bioptics, LLC, Tucson, USA) coupled to a computer to visualize the images of 3.7 MPx resolution. Subsequently, the seeds were individually analyzed in a computer screen, regarding their physical characteristics in the embryonic axis and in the endosperm, considering the classification adapted from Javorski et al. (2018) (Table 1).

The physiological quality was determined by germination and vigor tests. The germination was carried out with four replications of 50 seeds for each portion. These seeds were distributed on two sheets of Germitest paper moistened with water (equivalent to 2.5 times the mass of the paper). After that, the seeds were covered with a sheet to make the rolls, which were maintained in a BOD germination chamber at $25{ }^{\circ} \mathrm{C}$, in darkness. The first count occurred considering the normal seedlings (totally developed radicle and hypocotyl) at the third day, while the final count was carried out at the seventh day from sowing (Brasil 2009a).

As for the vigor test, the cold test was conducted in a paper roll without soil, similarly to the germination test, considering four replications of 50 seeds per portion. The rolls were initially maintained in a cold chamber at $10^{\circ} \mathrm{C}$, for 7 days, in darkness, and, after this period, they were removed and placed in a BOD germination chamber for additional 7 days, at $25^{\circ} \mathrm{C}$, in darkness. The evaluations were conducted analyzing the percentage of normal seedlings per portion.

To complete the information about the seed vigor, the root and shoot length were determined using seedlings from the germination test, and those classified as normal had their roots and shoots measured separately with the aid of a ruler. The same seedlings were placed in an oven with air circulation at $75{ }^{\circ} \mathrm{C}$, for 48 hours, and, after this period, they were removed and weighed in a precision scale to determine the dry seedlings mass.

The blotter test, used to evaluate the health quality, was carried out with four replications of 25 seeds for each portion. The seeds were uniformly distributed on three sheets of filter paper (previously sterilized and moistened with distilled water), which were placed in Petri dishes and taken to an incubation chamber at $20 \pm 2{ }^{\circ} \mathrm{C}$ and photoperiod of 12 hours, for seven days. After this period, the evaluation of each seed was performed by a stereoscopic and a compound microscope, recording the fungi found (Brasil 2009b).

The data, for each test, were initially evaluated by analysis of variance (Anova). The verification of normality of errors and homogeneity of variances was performed using the Shapiro-Wilk and Barlett tests, respectively. For significant effects between the portions, the means were compared by the Tukey test, at $5 \%$ of probability.

\section{RESULTS AND DISCUSSION}

The mean mass of millet seeds per panicle was of $25.457 \mathrm{~g}$ panicle $^{-1}$, of which $3.32 \mathrm{~g}(13.04 \%)$ refer to the proximal $1,6.52 \mathrm{~g}(25.55 \%)$ to the proximal $2,7.18 \mathrm{~g}(28.20 \%)$ to the intermediary, $5.95 \mathrm{~g}(23.37 \%)$ to the distal 1 and $2.47 \mathrm{~g}(9.70 \%)$ to the distal 2 portions. The two portions of the panicle end (proximal 1 and distal 2) presented the lowest masses, representing, together, $22.73 \%$ of

Table 1. Classification of the X-ray images of the millet seeds (adapted from Javorski et al. 2018).

\begin{tabular}{ll}
\hline \multicolumn{1}{c}{ Classification } & \multicolumn{1}{c}{ Seed characteristics } \\
\hline Intact & $\begin{array}{l}\text { Light gray/white coloration, without dark spots in any part of the seed and straight embryos occupying the } \\
\text { central position of the endosperm }\end{array}$ \\
\hline $\begin{array}{l}\text { Curved embryo } \\
\text { Light gray/white coloration, without dark spots in any part of the seed and twisted embryos, without } \\
\text { occupying the central portion of the endosperm }\end{array}$ \\
\hline Damaged & Mechanical damages, with cracks or breaks in any tissue, either in the embryo or in the endosperm \\
\hline Decayed & Dark spots in any part of the tissue, either in the embryo or in the endosperm, indicating a decayed tissue \\
\hline
\end{tabular}


the total seed mass in the panicle. This difference in seed mass is associated to the shape of the panicles, which have a lower diameter at the ends, interfering in the amount of seeds and, consequently, in the mass of these portions.

It was possible to identify size differences among the positions of the seeds in the panicle and in terms of their retention in the sieves (Figure 1). The $2 \times 12$ sieve presented the highest values for seed retention, when compared to the others and bottom. The intermediary portion of the panicle presented the highest values for seed mass in the $2 \times 12$ sieve, followed by the proximal 2 and distal 1 portions, respectively. This indicates that, although there are differences regarding the seed mass present in each portion, the size distribution of the seeds follows the same relation, with the highest concentration of seeds in the $2 \times 12$ sieve for all portions, except for distal 2.

Seeds from the distal 2 portion were not retained in the $2 \times 12$ sieve, but extended to the $3 \times 14$ sieve, indicating a lower size of the seeds in

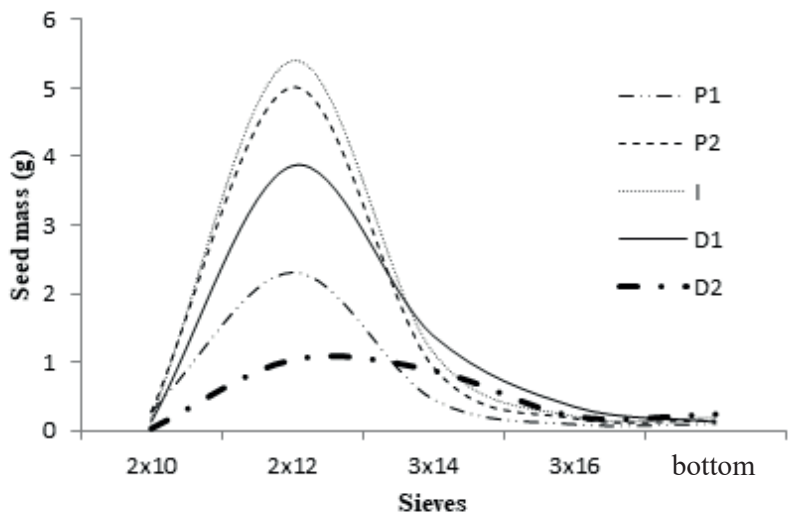

Figure 1. Seed mass distribution of each millet panicle portion [proximal $1(\mathrm{P} 1)$, proximal $2(\mathrm{P} 2)$, intermediate $(\mathrm{I})$, distal 1 (D1) and distal 2 (D2)], in each oblong sieve. this portion. Therefore, it is possible to confirm that there are differences among the seeds sizes at the different positions of the panicle.

The proximal 2 portion presented the highest retention percentage in the $2 \times 12$ sieve $(76.56 \%)$, followed by the sieves $3 \times 14$ (14.19\%), $2 \times 10$ $(4.22 \%), 3 \times 16(2.78 \%)$ and bottom $(2.25 \%)$. For the proximal 1 and intermediary portions, values above $70 \%$ of retention in the $2 \times 12$ sieve were also verified, and, in the distal 1 portion, this value was of $65.94 \%$. In the distal 2 portion, $43.16 \%$ of the seeds were retained in the $2 \times 12$ sieve and $36.61 \%$ retained in the $3 \times 14$ sieve, indicating a higher amount of smaller seeds than in the other portions. According to Pádua et al. (2010) and Hessel et al. (2012), different seed sizes and masses may interfere in their physiological potential; in other words, seeds with higher mass present, potentially, more developed seedlings, with a higher physiological quality.

The water content of the seeds (Table 2) varied from $8.9 \%$ to $9.1 \%$ in all positions, demonstrating that there was little variation regarding the position in the panicles.

Regarding the 1,000-seed mass, it was verified that the intermediary and proximal 2 positions are composed of seeds with a higher mass, followed by distal 1, proximal 1 and distal 2 . Batistella et al. (2002), studying the physical and physiological features of corn, evidenced that the position where the seed is formed has a direct influence on its mass, with those from the apex presenting lower means, similarly to what was verified in this research with millet. Lawan et al. (1985) and Gardner \& Vanderlip (1989) observed, for the millet crop, that germination and vigor are influenced by seed size, and they concluded that seeds with a higher mass present better responses, regarding the physiological potential.

Table 2. Water content (WC), 1,000-seed mass (1000SM) and X-ray test, considering intact seeds (I), seeds with curved embryo (C), damaged (D) and decayed (DS) seeds, for different positions of the panicle.

\begin{tabular}{lcccrrr}
\hline \multirow{2}{*}{ Portions } & \multirow{2}{*}{ WC $(\%)$} & \multirow{2}{*}{ 1000SM $(\mathrm{g})$} & \multicolumn{3}{c}{ X-ray $(\%)$} \\
\cline { 3 - 7 } & & & $\mathrm{I}$ & $\mathrm{C}$ & $\mathrm{D}$ & $\mathrm{DS}$ \\
\hline Proximal 1 & 9.1 & $7.66 \mathrm{~b}$ & $74 \mathrm{c}$ & $10 \mathrm{~b}$ & $1 \mathrm{a}$ & $15 \mathrm{a}$ \\
Proximal 2 & 9.0 & $9.08 \mathrm{a}$ & $85 \mathrm{~b}$ & $10 \mathrm{~b}$ & $1 \mathrm{a}$ & $4 \mathrm{~b}$ \\
Intermediary & 9.2 & $9.39 \mathrm{a}$ & $95 \mathrm{a}$ & $1 \mathrm{c}$ & $1 \mathrm{a}$ & $3 \mathrm{~b}$ \\
Distal 1 & 8.9 & $7.99 \mathrm{~b}$ & $76 \mathrm{c}$ & $9 \mathrm{~b}$ & $0 \mathrm{a}$ & $15 \mathrm{a}$ \\
Distal 2 & 9.1 & $6.42 \mathrm{c}$ & $69 \mathrm{c}$ & $17 \mathrm{a}$ & $1 \mathrm{a}$ & $13 \mathrm{a}$ \\
\hline $\mathrm{CV}(\%)$ & & 2.56 & 5.19 & 12.74 & 4.32 & 25.31 \\
\hline
\end{tabular}

* Means followed by the same letter in the column do not differ at $5 \%$ of probability by the Tukey test. 
In a study with eight millet varieties, Sugri et al. (2011) verified that plants derived from bigger seeds develop faster until they reach the phenological phase with three to five leaves. Thus, the producer can anticipated the gains, due to the shorter period until the first cut of the forage plant (Bernardi et al. 2019).

By the X-ray tests, intact seeds (Figure 2A) and seeds with curved embryo (Figure 2B), damaged (Figure 2C) or with decay spots (Figure 2D) were observed. The highest number of intact seeds evaluated by the X-ray test was observed for the seeds of the intermediary portion (Table 2).

In the distal 2 portion, a higher amount of seeds with curved embryo was observed, while, for the proximal 1, distal 1 and distal 2 portions, a higher amount of seeds with decay spots was observed, in relation to the other portions. According to Mondo \& Cicero (2005), the presence of a curved embryo in corn seeds is not the cause of reduction in the seed quality. They observed, in the distal and proximal portions, a higher incidence of corn seeds with curved embryo, when compared to the seeds of the other portions; nonetheless, even with twists, most of the seeds developed normal seedlings.

On the other hand, decay spots indicate less dense tissues, probably because of malformation or attack of field fungi during the seed formation, what compromises their final quality. The highest proportion of decayed seeds was observed in the proximal 1, distal 1 and distal 2 portions. Javorski et al. (2018) identified that millet seeds with decay spots in their tissues, mainly extending to the embryonic axis, cause seed death or formation of abnormal seedlings.

The X-ray test was efficient in the evaluation of abnormalities in the internal morphology of the millet seeds and is a very important tool to help in the interpretation of responses to morphological factors that interfere in seed quality (Javorski et al. 2018).

Regarding the millet seed germination, there is a normative instruction that determines a trade pattern of $75 \%$ for germination (Brasil 2008). Thus, only the intermediary, distal 1 and distal 2 portions would meet the trade pattern for this crop (Table 3 ). The

Table 3. Germination (G), germination after the cold test (CT), seedling root length (SRL), seedling shoot length (SSL) and dry matter mass of millet seedlings (MMS) for seeds from different panicle positions.

\begin{tabular}{lccccc}
\hline \multicolumn{1}{c}{ Portions } & $\mathrm{G}(\%)$ & $\mathrm{CT}(\%)$ & SRL $(\mathrm{cm})$ & SSL $(\mathrm{cm})$ & $\mathrm{MWS}(\mathrm{g})$ \\
\hline Proximal 1 & $66 \mathrm{c}$ & $26 \mathrm{c}^{*}$ & $12.06 \mathrm{a}$ & $4.58 \mathrm{ab}$ & $0.168 \mathrm{~b}$ \\
Proximal 2 & $72 \mathrm{bc}$ & $34 \mathrm{c}$ & $10.25 \mathrm{bc}$ & $4.23 \mathrm{ab}$ & $0.182 \mathrm{ab}$ \\
Intermediary & $85 \mathrm{a}$ & $64 \mathrm{a}$ & $11.65 \mathrm{ab}$ & $4.70 \mathrm{a}$ & $0.210 \mathrm{a}$ \\
Distal 1 & $76 \mathrm{ab}$ & $52 \mathrm{~b}$ & $11.04 \mathrm{abc}$ & $3.90 \mathrm{~b}$ & $0.166 \mathrm{~b}$ \\
Distal 2 & $85 \mathrm{a}$ & $29 \mathrm{c}$ & $9.74 \mathrm{c}$ & $4.72 \mathrm{a}$ & $0.166 \mathrm{~b}$ \\
\hline CV $(\%)$ & 4.49 & 10.91 & 6.59 & 7.43 & 7.47 \\
\hline
\end{tabular}

* Means followed by the same letter in the column do not differ at $5 \%$ of probability by the Tukey test.
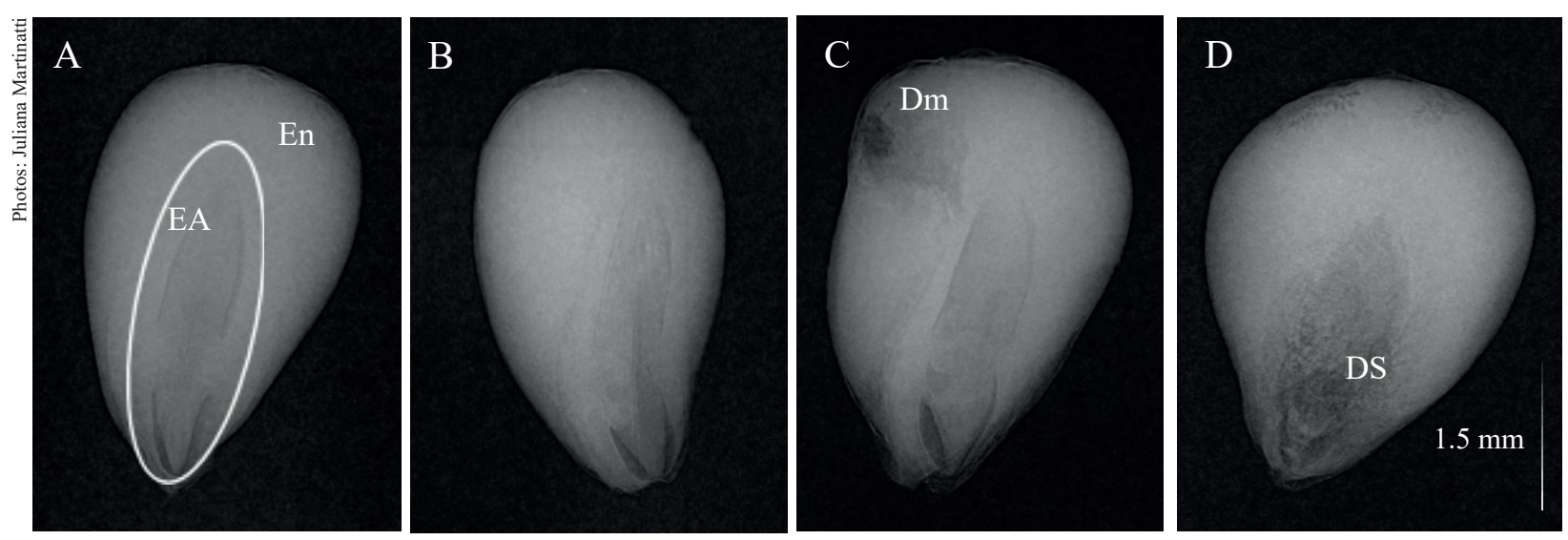

Figure 2. X-rayed millet seeds (A: whole seed; B: seed with curved embryo; C: damaged seed; D: decayed seed; EA: embryonic axis; En: endosperm; Dm: damage; DS: decay spot). 
seeds from the proximal 1 and proximal 2 portions presented a lower germination percentage, when compared to the intermediary and distal 2 portions (Table 3). The seeds from the proximal portions refer to those which are at the base of the panicles, a region that can be more prone to water accumulation after the occurrence of rain during the formation stage. This water accumulation promotes deterioration and attack of fungi. These fungi act directly on the seed reserve organs, compromising its germination capacity (Krishnan et al. 2019).

Taking into account all the seeds from all the panicles portions, those from the proximal 1 and proximal 2 portions contributed to the reduction of the quality of the seed lot as a whole. Therefore, the separation of these materials for seed processing would benefit in obtaining a seed lot of higher quality. The seeds from the proximal 1 and proximal 2 portions, which presented the lowest viability by the germination test, corresponded to $38.63 \%$ of the total seed mass of the panicle, representing an expressive amount in the production process. Separating only the seeds from the proximal 1 portion, that is, those with lower germination, only $13.03 \%$ of the seeds would be discarded, increasing the total germination of the lot.

Bernardi et al. (2019) studied the physiological quality of Sudan grass (Sorghum sudanense L.) seeds of different sizes, standardized based on density, and concluded that bigger seeds promote superior rates of seedling germination and growth, in addition to a higher forage yield until the first cut of the crop.

Silva et al. (2015), evaluating the effect of the position of passion fruit seeds, in terms of germination and emergence, did not verify any interference in seed quality as a consequence of their distal, median or proximal position. According to the authors, this may occur because passion fruit is a fleshy fruit, what hampers possible effects of adverse factors.

It is worth highlighting that seed lots with similar germination percentages might not present the same vigor, and, consequently, the vigor tests assisted in the careful definition of which portion promotes the highest physiological quality of millet seeds (Table 3 ).

In the cold test without soil (Table 3 ), the highest germination was observed for the seeds from the intermediary portion, followed by distal 1 , in relation to the other portions. Regarding the length of the root system, the proximal 1 and intermediary portions were superior to distal 2. For the shoot length of the seedlings, the intermediary and distal 2 portions were superior to distal 1 . The intermediary portion presented the highest seedling dry matter mass, when compared to proximal 1 , distal 1 and distal 2 (Table 3).

The evaluation of vigor must be performed considering a set of tests, which will allow the inference on the potential of these seeds to promote a fast and uniform seedling germination, either under field stress conditions or after a storage period (Marcos Filho 2015). It is worth highlighting for this study that, considering only the data from a single vigor test, the classification of the portions with higher vigor would not be the same as that observed considering the whole set of tests.

It is possible to infer that the higher vigor may be attributed to the seeds derived from the intermediary portion, following the trend of superior quality verified by the germination (Table 3) and X-ray (Table 2) tests. Therefore, the highest quality of the seeds from the intermediary portion is related to the formation of bigger and fully formed seeds, with a lower occurrence of decaying tissues, maximizing the formation of normal seedlings and the establishment of an appropriate stand.

Alves \& Krist (2011) obtained differences, regarding the 1,000-seed mass, germination and vigor for oat seeds, when divided into primary, secondary and tertiary branches. For corn seeds, those located in the proximal portion of the cob had a higher quality, if compared to those located in the distal portion (Mondo \& Cicero 2005). The authors indicated that the presence of a higher amount of phytopathogenic fungi, such as Fusarium moliniforme and Penicillium spp., in the distal portion of the corn cobs is the main cause of the drop in seed quality. In the distal portion of the cobs, the seeds are more prone to the attack of fungi and pests, as well as to environmental adversities, becoming more susceptible to quality loss.

In the blotter test, the occurrence of Fusarium sp. was verified in seeds from all portions, with the highest occurrence being verified in the proximal 1 portion (Table 4), contributing to the lower germination and vigor of the seeds from this portion (Tables 2 and 3). The occurrence of a greater amount of Fusarium sp. at the base of the 
Table 4. Fusarium sp. and Coletotrichum sp. occurrence in millet seeds from different panicle positions obtained from the blotter test.

\begin{tabular}{lcc}
\hline \multicolumn{1}{c}{ Portions } & Fusarium sp. & Colletotrichum $\mathrm{sp}$. \\
\hline Proximal 1 & $22 \mathrm{a}$ & $3 \mathrm{a}$ \\
Proximal 2 & $9 \mathrm{~b}$ & $1 \mathrm{ab}$ \\
Intermediary & $6 \mathrm{~b}$ & $4 \mathrm{a}$ \\
Distal 1 & $9 \mathrm{~b}$ & $0 \mathrm{~b}$ \\
Distal 2 & $11 \mathrm{~b}$ & $1 \mathrm{ab}$ \\
\hline CV (\%) & 30.58 & 86.07 \\
\hline
\end{tabular}

* Means followed by the same letter in the column do not differ at $5 \%$ of probability by the Tukey test.

panicle is because this is a wetter region during the seed formation, and more prone to the attack of this fungi.

The Colletotrichum sp. species was identified in a smaller amount, when compared to Fusarium sp., indicating that it has little interference on the physiological potential. Adbel-Hafez et al. (2017) also identified, among several fungi associated to millet seeds, the presence of Fusarium sp. and Colletotrichum sp. Bankefa et al. (2020), aiming at the identification of fungi associated to millet seeds, in samples in Nigeria, also identified Fusarium sp. in the samples. These authors verified a great occurrence of storage fungi, such as Aspergillus sp. and Penicillium sp., what was not observed in this study, since the seeds were immediately subjected to the blotter test right after their harvest.

It is important to highlight that the infection by several fungi not only interferes in the reduction of the seed physiological potential, but it may also contaminate grains with mycotoxins (Atanda et al. 2013), causing the contamination of people and animals that feed on these grains. This occurs primarily in the contamination by Aspergillus sp. and by other storage fungi not detected in this study. In addition, researches have identified the presence of aflatoxin and fuminosin produced by Fusarium species (Chehri \& Abod 2017).

\section{CONCLUSION}

Seeds located at different portions of the millet panicles present differences regarding physical, physiological and health quality, with those derived from the intermediary portion presenting the highest quality and percentage of intact seeds.

\section{ACKNOWLEDGMENTS}

To the Prof. Dr. Francisco Guilhien Gomes Junior, responsible for the Seed Image Analysis Laboratory of the ESALQ/USP, and the Researcher Clíssia Barboza da Silva (FAPESP/ESALQ/USP, Project\#2018/03807-6).

\section{REFERENCES}

ABDEL-HAFEZI, A. I. I.; ADBEL-SATERI, M. A.; HUSSEIN, N. A.; ABDEL-WAHAPAL-AMERY, E. Fungal diversity associated with pearl millet (Pennisetum glaucum L.) grains from Taiz governorate, Yemen and their amylase production. Journal of Microbiology, Biotechnology and Food Sciences, v. 7, n. 2, p. 118-123, 2017.

ALVES, A. C.; KIST, V. Qualidade fisiológica de sementes primárias, secundárias e terciárias da espigueta de aveia branca (Avena sativa L.). Revista Brasileira de Agrociência, v. 17, n. 1-4, p. 153-157, 2011.

ATANDA, O. O.; AKANO, D. A.; AFOLABI, J. F. Mycoflora of dry 'tatase' pepper (Capsicum annum L.) stored for sale in Ibadan markets. Letters Applied Microbiology, v. 10, n. 1, p. 35-37, 2013.

BANKEFA, B. A.; UWAGA, I.; AKINTOBI, O. A.; ADEJUWON, A. O.; UMEZURIKE, E. T.; BALOGUN, O.; OBAYEMI, O. S. Mycoflora associated with millet (Penissetum glaucum L.) purchased from major markets in Ibadan Metropolis, Nigeria. Advances in Bioscience and Bioengineering, v. 8, n. 1, p. 1-23, 2020.

BATISTELLA, F.; MORO, F. V.; CARVALHO, N. M. de. Relationships between physical, morphological, and physiological characteristics of seeds developed at different positions of the ear of two maize (Zea mays L.) hybrids. Seed Science and Technology, v. 30, n. 1, p. 97106, 2002.

BERNARDI, A.; RAMOS, A. R.; SILVA, A. W. L. da. Seed size affects productive parameters in Sudan grass. Ciência Rural, v. 49, n. 4, p. 1-6, 2019.

BRASIL. Ministério da Agricultura, Pecuária e Abastecimento. Instrução Normativa $n^{\circ} 30$ de 21 de maio de 2008. Normas e padrões para produção e comercialização de sementes de espécies forrageiras de clima tropical. Diário Oficial da União: seção 1: Poder Executivo, Brasília, DF, p. 45, 23 maio 2008.

BRASIL. Ministério da Agricultura, Pecuária e Abastecimento. Normas para a análise sanitária de sementes. Brasília, DF: MAPA/ACS, 2009b. 
BRASIL. Ministério da Agricultura, Pecuária e Abastecimento. Regras para análise de sementes. Brasília, DF: MAPA/ACS, 2009a.

BUSO, W. H. D.; FRANÇA, A. F. S.; MIYAGI, E. S. Bromatological composition and dry matter digestibility of millet cultivars subjected to nitrogen doses. Arquivo Brasileiro de Medicina Veterinária e Zootecnia, v. 66, n. 3, p. 887-893, 2014.

CHEHRI, K.; ABOD, H. S. Detection of fuminisin chenotype produced by Fusarium proliferatum isolated from nuts in Iraq using specific PCR assays. Biological Journal of Microorganism, v. 6, n. 24, p. 21-27, 2017.

COSSETIN NETO, G.; BONETTI, L. P. Avaliação da qualidade física e fisiológica de sementes de milho crioulo em relação à posição na espiga. In: SEMINÁRIO INTERINSTITUCIONAL, 18., 2013, Cruz Alta. Anais... Cruz Alta: Universidade de Cruz Alta, 2013. p. 1-5.

FOGAÇA, J. J. N. L.; SILVA, R. A.; SANTOS, J. L.; NUNES, R. T. C.; FERREIRA, L. L.; MORAIS, O. M. Qualidade fisiológica de sementes de mamona crioula var. Carrapatinho em função da posição do rácemo. Revista de Ciências Agrárias, v. 40, n. 1, p. 87-93, 2017.

GARDNER, J. C.; VANDERLIP, R. L. Seed size and density effects on field performance of pearl millet. Transactions of the Kansas Academy of Science, v. 92, n. 1-2, p. 49-59, 1989.

GRZYBOWSKI, C. R. de S.; VIEIRA, E. S. N.; PANOBOANCO, M. Processing and physical and physiological quality of the native forest seeds of Vernonanthura discolor. Acta Scientiarum: Agronomy, v. 41, n. 1, e39574, 2019.

HAN, Z.; KU, L.; ZHANG, Z.; ZHANG, J.; GUO, S.; LIU, H.; ZHAO, R.; REN, Z.; ZHANG, L.; SU, H.; DONG, L.; CHEN, Y. QTLs for seed vigor-related traits identified in maize seeds germinated under artificial aging conditions. PloS One, v. 9, n. 3, e92535, 2014.

HESSEL, C. L. E.; VILLELA, F. A.; AUMONDE, T. Z.; PEDÓ, T. Mesa densimétrica e qualidade fisiológica de sementes de brachiária. Informativo Abrates, v. 22, n. 3, p. 73-76, 2012.

JAVORSKI, M.; CASTAN, D. O. C.; SILVA, S. S.; GOMES-JUNIOR, F. G.; CICERO, S. M. Image analysis to evaluate the physiological potential and morphology of pearl millet seeds. Journal of Seed Science, v. 40, n. 2 , p. 127-134, 2018.

KONG, D.; FU, X.; JIA, X.; WANG, W.; LI, Y.; LI, J.; YANG, X.; JU, C. Identification of quantitative trait loci controlling ethylene production in germinating seeds in maize (Zea mays L.). Scientific Reports, v. 10, n. 1, p. 1-9, 2020.
KRISHNAN, N.; VELRAMAR, B.; VELU, R. K. Investigation of antifungal activity of surfactin against mycotoxigenic phytopathogenic fungus Fusarium moniliforme and its impact in seed germination and mycotoxicosis. Pesticide Biochemistry and Physiology, v. 155, n. 1, p. 101-107, 2019.

LAWAN, M.; BARNETT, F. L.; KHALEEQ, B.; VANDERLIP, R. L. Seed density and seed size of pearl millet as related to field emergence and several seed and seedling traits. Agronomy Journal, v. 77, n. 4, p. 567-571, 1985.

MARCOS FILHO, J. Fisiologia de sementes de plantas cultivadas. Piracicaba: Fealq, 2015.

MONDO, V. H. V.; CICERO, S. M. Análise de imagens na avaliação da qualidade de sementes de milho localizadas em diferentes posições na espiga. Revista Brasileira de Sementes, v. 27, n. 1, p. 9-18, 2005.

PÁDUA, G. P.; ZITO, R. K.; ARANTES, N. E.; FRANÇA NETO, J. B. Influência do tamanho da semente na qualidade fisiológica e na produtividade da cultura da soja. Revista Brasileira de Sementes, v. 32, n. 3, p. 9-26, 2010.

PEREIRA FILHO, I. A. Cultivo do milheto. 5. ed. Sete Lagoas: Embrapa Milho e Sorgo, 2016.

PESKE, F. B.; NOVEMBRE, A. D. L. C. Condicionamento fisiológico de sementes de milheto. Revista Brasileira de Sementes, v. 32, n. 4, p. 132-142, 2010.

PIRES, F. R.; ASSIS, R. L.; SILVA, G. P.; BRAZ, A. J. B. P.; SANTOS, S. C.; VIEIRA NETO, S. A.; SOUSA, J. P. G. Desempenho agronômico de variedades de milheto em razão da fenologia em pré-safra. Bioscience Journal, v. 23, n. 3, p. 41-49, 2017.

ROSSI, R. F.; CAVARIANI, C.; FRANÇA NETO, J. B. Vigor de sementes, população de plantas e desempenho agronômico de soja. Amazonian Journal of Agricultural and Environmental Sciences, v. 60, n. 3, p. 215-222, 2017.

SANTOS, G. R.; TSCHOEKE, P. H.; SILVA, L. G.; SILVEIRA, M. C. A. C.; REIS, H. B.; BRITO, D. R.; CARLOS, D. S. Sanitary analysis, transmission and pathogenicity of fungi associated with forage plant seeds in tropical regions of Brazil. Journal of Seed Science, v. 36, n. 1, p. 54-62, 2014.

SILVA, S. M.; OLIVEIRA, R. C.; ALMEIDA, R. F.; SÁ JUNIOR, A.; SANTOS, C. M. Aryl removal methods and passion fruit seed position: germination and emergence. Journal of Seed Science, v. 37, n. 2, p. 125-130, 2015.

SUGRI, I.; NUTSUGAH, S. K.; YIRZAGLA, J. Effect of some seed physical characteristics on viability of pearl millet (Pennisetum glaucum (L.) R. Brown). Research Journal of Seed Science, v. 4, n. 4, p. 181-191, 2011. 